Alison Butler

Alison Butler is an economist at the Federal Reserve Bank of St. Louis. David H. Kelly provided research assistance.

The author would also like to thank Richard Blackhurst for his assistance.

\title{
Environmental Protection and Free Trade: Are They Mutually Exclusive?
}

Having to compete in the United States in a totally free market atmosphere with companies and countries who have yet to develop such environmental standards is inherently unfair. It puts us into a game where the unevenness of the rules almost assure that we cannot win or even hold our own.

James E. Hermesdorf, Testimony to Senate Finance Committee on Trade and the Environment, October 25, 1991.

OMMENTS LIKE THE ONE cited above are being heard with increasing frequency. In fact, protecting the environment has always had implications for international trade. In 1906, for example, the United States barred the importation of insects that could harm crops or forests. Similarly, the Alaska Fisheries Act of 1926 established federal regulation of nets and other fish. ing gear and made it illegal to import salmon from waters outside U.S. jurisdiction that violated these regulations. More recently, a U.S. law restricting the method of harvesting tuna to protect dolphins has been the subject of a trade dispute between the United States and Mexico.

In recent years, as global warming and other environmental concerns have multiplied, environmental issues have played an increasing role in trade negotiations, further complicating what are generally difficult negotiations. Negotiating environmental regulations multilaterally is especially problematic because of differences in preferences and income levels across countries. What's more, scientific evidence is not always conclusive on the effects of certain types of environmental degradation. Finally, environmental considerations can be used to disguise protectionist policies.

This paper examines the different ways environmental policy can have international ramifications and their implications for international trade and international trade agreements. A general introduction to environmental economics is given, followed by an analysis of the relationship between environmental policy and 
international trade. The paper concludes with a discussion of the status of environmental considerations in multilateral trade agreements.

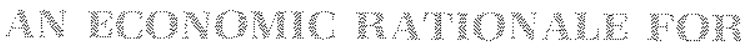 Wha k}

The environment is used primarily in three ways: as a consumption good, a supplier of resources and a receptacle of wastes. ${ }^{1}$ These three uses may conflict with one another. For example, using a river as a receptacle of wastes can conflict with its use as a supplier of resources and as a consumption good. ${ }^{2}$ When either the production or consumption of a good causes a cost that is not reflected in a market price, market failures that are termed "externalities" may exist. ${ }^{3}$ Such market failures frequently involve the environment.

A. C. Pigou, in The Economics of Welfare (originally published in 1920), presented one of the classic examples of an externality. In the early 1900s, many towns in Great Britain were heavily polluted by smoke coming from factory chimneys. Laundered clothes hung outside to dry were dirtied by the smoke. A study done in the heavily polluted city of Manchester in 1918 compared the cost of household washing in that city with that of the relatively eleaner city of Harrogate. According to the Manchester Air Pollution Advisory Board:

The total loss for the whole city, taking the extra cost of fuel and washing materials alone, disregarding the extra labour involved, and as. suming no greater loss for middle-class than for working-class households fa considerable under. statement), works out at over $£ 290,000$ a year for a population of three quarters of a million. ${ }^{4}$

Thus, a by-product of production-smokeunintentionally had a negative effect on another economic activity-clothes-washing.

\footnotetext{
${ }^{3}$ There are many definitions of what constitutes the enviroment and therefore what is environmental damage. Production polution results from the act of producing a product. Consumption polution arises when the act of con* suming a product causes pollution. Deforestation reduces both the capacity of the earth to naturally process carbon dioxide and biological diversity. Eimination of a biological species also has envifonmental implications. Other things that have environmental consequences include product safety standards (such as limiting chemicals that can be used in agriculture) and sot erosion. This paper, unless otherwise noted, focuses on production pollution, the source of many trade-related disputes.
}

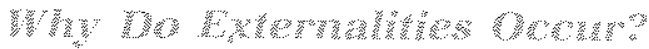

Externalities exist when the social cost of an activity differs from the private cost because of the absence of property rights. In the preceding example, because no one "owns" the air, the factory does not take into account the extra washing costs it imposes on the citizens of the town. As a result, more pollution than is socially optimal will occur because the private cost of the smoke emissions to the firm (zero) is lower than the social cost $(£ 290,000$ a year). In general, if nothing is done about negative externalities, environmental damage will result as ecologically harmful products are overproduced and the environment is overused.

To eliminate externalities, the divergence between the social and private costs must be eliminated, either by assigning private property rights (that is, ownership rights) or by direct government regulation. The approach taken often depends on whether property rights can be assigned. ${ }^{5}$ The advantage of assigning property rights to an externality is that it creates a market for that product and allows the price mechanism to reflect the value of the externality.

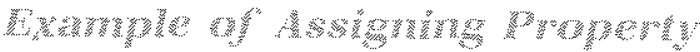

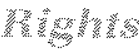

Suppose a chemical factory locates upstream from a small town and emits waste into the river as part of its production process. Suppose further that the town uses the river as its primary source of water. As a result of these emissions, the town must process the water before use. Clearly there is an externality associated with the firm's use of the water-it is no longer usable to the town without cost. If property rights to the river could be assigned to either the town or the firm, then the two par. ties could bargain for the most efficient level of pollutants in the water.
${ }^{2}$ For a more detailed discussion of these probtems, see siebert (1987).

3This paper tocuses only on negative externalities. Positive envirommental externalities occur when one use of the environment costlessly enhances another. For example, cleaning a river for recreational use could also increase its function as a supplier of fish.

4 Pigou (1952), p.185, footnote 18.

${ }^{5}$ Even if they can, social mores or standards may prevent such an assignment. For example, people might be opposed to selling timber companies the property ights to all trees in national forests. 
If property rights are assigned to the firm, the town pays the firm to reduce its pollution. The town's willingness to pay for reduced levels of pollution depends on the benefits it receives from cleaner water. Generally speaking, as the water becomes more pure, the additional (marginal) benefits to the town likely decrease. On the other hand, the firm's willingness to reduce pollution depends on the costs it incurs to reduce pollution by, for example, changing to a more costly production or waste-disposal method. Generally speaking, as the firm pollutes less, the additional (marginal) costs to the firm increase. The amount of pollution agreed upon will be such that the added benefits to the town of a further reduction in pollution are less than the added costs to the firm of the further reduction.

If property rights are assigned to the town, on the other hand, the firm pays the town to pollute. The firm's willingness to pay for the right to pollute depends on the benefits it receives from polluting. These benefits are directly related to the costs it incurs from using a more costly production or waste-disposal method. Similarly, the town's willingness to sell pollution rights depends on the costs it incurs from additional pollution. The amount of pollution agreed upon is where the additional benefits to the firm of increasing pollution are less than the additional costs to the town of additional pollution.

The Coase theorem proves that the equilibrium level of pollution is the same in the preceding cases. Furthermore, such an outcome is efficient. ${ }^{6}$ Thus, when property rights are clearly defined and there is an explicitly designated polluter and victim, the efficient outcome is independent of how the property rights are assigned.

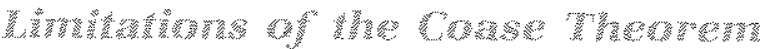

The key result of the Coase theorem, that the allocation of property rights does not affect the efficient amount of pollution, has limited application. If there are multiple polluters and/or many parties affected by the pollution, the outcome can depend on how property rights are assigned. Similarly, if there are significant trans- actions costs, such as measurement and enforcement costs, the Coase theorem may not hold. ${ }^{7}$

Assume, for example, that two towns are affected by the factory's emissions, one further downstream than the other. Suppose that the town further away from the chemical plant has lower costs associated with cleaning the water. In this case, the amount of compensation the towns would be willing to pay to reduce emissions by any given amount would differ. Thus, the allocation of property rights among the firm and the two towns would affect the outcome of their bargaining.

Suppose, instead, that more than one firm is polluting. Determining how much pollution is coming from each firm, along with ensuring that each firm lives up to any agreement, may be difficult and costly. If monitoring costs are high, the Coase theorem may not hold and the allocation of property rights again affects the choice of optimal emissions.

The lack of general applicability of the coase theorem is not an indictment of using marketoriented incentives (which usually requires assigning property rights). Most economists believe that market-oriented solutions will lead to the most efficient use of resources because, rather than having the government attempt to estimate preferences, it allows the market mechanism to reveal them.

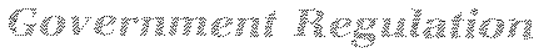

Property rights are not always assigned because many uses of the environment are considered public goods. A pure public good is one that has two qualities: First, it is impossible or extremely costly to exclude people from the benefits or costs of the good (non-excludability). For example, even if a person does not contribute to cleaning the air, she still cannot be excluded from breathing the cleaner air. Second, the consumption of the good by one person does not diminish the amount of that good available to someone else (non-rivalry). For example, the fact that one person is breathing clean air does not reduce the amount of clean air others breathe. In this case, property rights cannot be assigned because rationing is impossible.
6See Coase (1960). An (Pareto) efficient outcome is one in which no one can be made better off without making someone else worse off. This iype of economic efficiency, however, provides no information or guidance regarding equity issues. For a graphical analysis, see Nicholson (1985).
7For a discussion of the limitations of the Coase theorem, see Baumol and Oates (1988). 
While few uses of the enviromment are pure public goods like air, many have enough features of non-excludability and non-rivalry to make assigning property rights virtually impossible. The functions of the environment that are public goods, such as breathable air and clean water, are summarized by the term environmen. tal quality.

Regulating environmental quality is difficult because the government first needs to determine the public's demand for environmental quality before deciding the efficient level of pollution. The free-rider problem that occurs with public goods makes this determination especially difficult. When people cannot be excluded from use, they have an incentive to understate their willingness to pay for environmental quality because they can gamble that others will be willing to pay. Similarly, if they are asked their preferences and know they will not have to pay, people have an incentive to overstate their desire for a given public good. The degree to which free-riding is a problem depends on the size of the non-rival group affected. The larger the group, the greater the free-rider problem. ${ }^{s}$

For the purposes of this paper, we will assume that to determine the "true" value of public goods, the government measures the costs of pollution reduction and the benefits of pollution abatement accurately. ${ }^{9}$ Using a costbenefit approach, the optimal outcome is where the marginal cost of pollution reduction equals the marginal benefit of pollution abatement. ${ }^{10}$
It is important to recognize that the socially optimal level of pollution is generally not zero. Achieving zero pollution would require an extremely low level of production or an extremely high cost of pollution control. In determining the optimal amount of pollution, both the costs to individuals and industry need to be taken into account, ${ }^{11}$

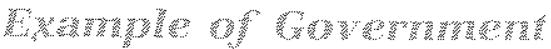

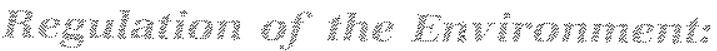

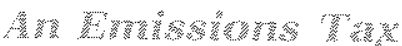

Recall the previous example of a firm emitting pollutants into a river, Suppose the government decides to regulate the industry because there are too many polluting firms on the river to define property rights adequately. ${ }^{2}$ After determining the socially optimal level of pollution, the government imposes a per-unit tax on emissions to reduce pollution to the optimal level. ${ }^{13}$

What happens to production? Figure 1 shows the supply and demand curves for the indus: try's output. The effect of the tax is to shift the supply curve the distance $A B$ (the additional per-unit cost of output given the new tax). ${ }^{14}$ The price rises from $P_{1}$ to $P_{2}$, and the quantity of output falls from $Q_{1}$ to $Q_{2}$, which is the output level associated with the efficient emission level. ${ }^{15}$ Emissions are reduced and environmental quality improves.
BHow to avoid this problem is the source of vast jiterature in economics and is not discussed in detail here. For a discussion of the freerider problem in valuing public goods, see Browning and Browning (1983), or any other public finance textbook.

'Significant problems face governmental agencies trying to determine the optimal amount of environmental quality. For a discussion of these issues, see Baumol and Oates (1988), Siebert (1987), and Anderson and Blackhurst (1992). For an evaluation of how successful current methods are in the United States, see OECD (1991).

${ }^{10}$ For a more detailed study of cost-benefit analysis, see $\mathrm{M}$. shan (1971).

${ }^{11}$ While it is difficuli for many people to think of placing a monetary value on health and life, in reality it is done all the time. For example, though many lives are lost in cars each year, people are not willing to pay the "costs" of outlawing cars to save those lives. For an excellent discussion of this issue, see Blackhurst (1977), footnote 18 .

$\$ 2$ For simplicity, we assume all firms on the river produce the same product and constitute the entire industry. This analysis can be generalized, but it greatly complicates the graphical analysis.
${ }^{13}$ This analysis assumes that the cost of reducing pollution per unit is the same across firms in this industry. One problem with imposing a per-unt tax, however, is that the cost of reducing pollution can vary significantly across firms. One innovative approach to finding the most efficient way to reduce pollution to a given level is the trading of emission permits. In this case, the government decides the maximum amount of each type of polutant that can be emitted overall and distributes permits to firms, allowing them each a certain level of polluting emissions. The permits can be traded among firms, which allows firms to use firm-specific information to set their own level of pollution. This enables firms for which installing pollution controls is relatively inexpensive to sell emission permits to firms that find it more expensive to install pollution-reduction devices. For a discussion of the theory of emission trad" ing, see Tietenberg (1990) and Nicolaisen, Dean and Hoeller (1991). For a discussion of the effectiveness of emission trading in the United States, see OECD (1991).

74 This assumes that the per-unit emissions tax increases the cost of production proportionately.

15Other means of reducing pollution, such as a tax credil for pollution reduction, may not result in tower output in the industry. 


\section{Figure 1 \\ The Effect of an Emissions Tax on Industry Price and Output}

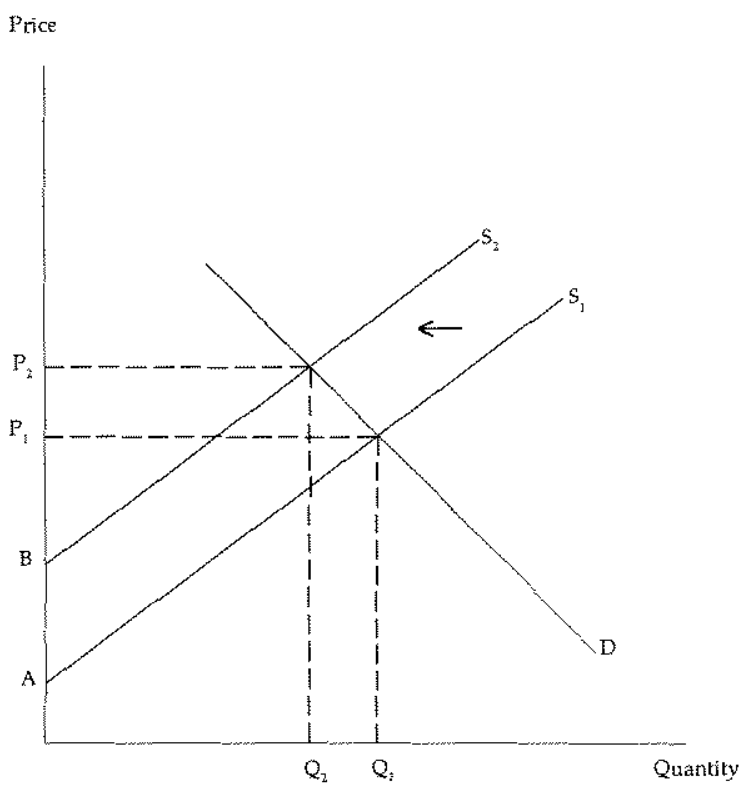

‥6\%

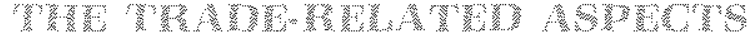

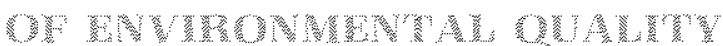

Pollution can have international effects in two ways. First, it might be localized within national boundaries but, through the impact of environmental policy, affect a country's international trade. On the other hand, pollution may be transported across borders without the consent of the countries affected (so-called transfrontier pollution. These two types of environmental damage have different effects on international trade and, therefore, are discussed separately.

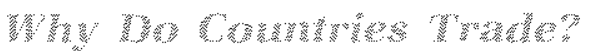

Countries trade because of differences in comparative advantage. The idea of comparative advantage suggests that, given demand, countries should export products that they can produce relatively cheaply and import products for which they have a relative cost disadvan- tage. Traditional international trade models ig. nore externalities such as non-priced uses of the environment.

By not explicitly including the environment as a factor of production, the costs associated with using the environment are ignored. More recent economic models have extended the definition of factors to include assimilative capacity, that is, the capacity of the environment to reduce pollutants by natural processes. The degree to which the environment will be affected by its use or by the production of ecologically harmful products depends on its assimilative capacity. The higher the assimilative capacity, the less the environmental damage caused by the emission of a given amount of pollutants. Assimilative capacity can differ across regions and countries and thus is an important factor in determining the effects of environmental use on trade.

Traditional trade models also ignore the nonpriced use of the environment as a consumption good. This underestimates the value consumers may place on the environment and therefore the cost of using the environment for other functions. These two factors can be significant in determining a country's comparative advantage. ${ }^{16}$

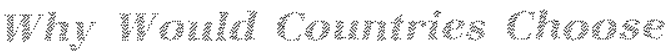

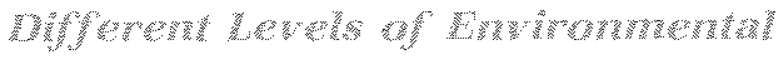

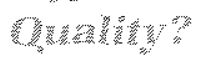

Assimilative capacity is one of the principal factors affecting a country's choice of environmental quality. In general, assimilative capacity is lower in industrialized countries because of the effects of past pollution. Less-industrialized countries often have greater assimilative capacities and thus can tolerate a higher level of emissions without increasing pollution levels. Population density and geography also affect a country's assimilative capacity. For example, the introduction of a polluting industry in a sparsely populated area, all else equal, will likely not affect the assimilative capacity of that area as much as it would in a densely populated area.

Other factors can also affect a country's will. ingness to accept environmental degradation.

take into account the costs of irreversible environmental destruction, so that, for example, the costs (as well as the benefits) of rapid deforestation are accurately reflected in measures of output growth and wealth.
Recently some have suggested that the United Nation change its system of national accounts to take into account environmentai resources. This can be particularly important for countries like Costa Rica that have large en vironmental resources (see "Wealth of Nalure," January 18, 1992). A different system of national accounting coutd 
Figure 2

The Effect of an Emissions Tax on Industry Price and Output in a Two-Country World
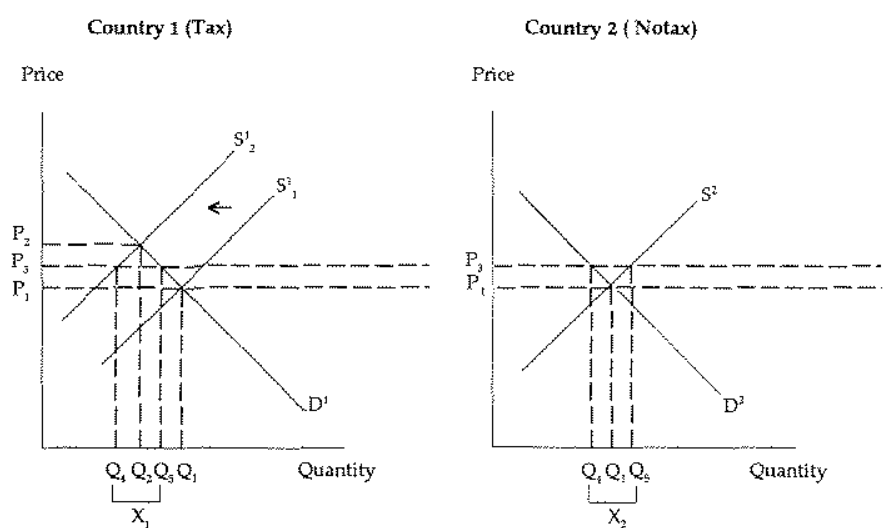

World Supply and Demand

Price

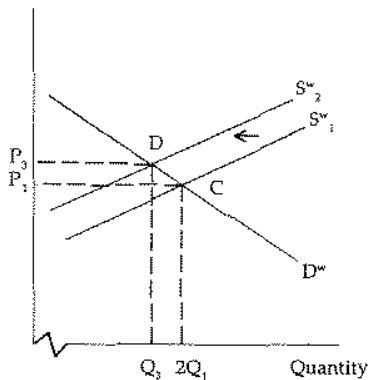

For example, poor countries may put a higher priority on the benefits of production (such as higher employment and incomel relative to the benefits of environmental quality than wealthy countries. As income levels increase, however, demand for environmental quality also rises. ${ }^{17}$ Thus, countries with similar assimilative capacities might choose different levels of environmental quality. As the example below demonstrates, environmental policies that result from differ. ences in countries' preferences and income levels can have significant trade effects.

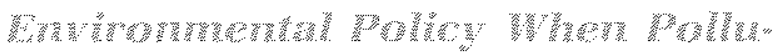

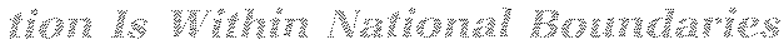

How does environmental policy affect trade? Recall that, in the emissions tax example, the higher production costs that resulted from the tax caused the price of the industry's output to increase and the quantity produced to fall. Assume there is a chemical industry in another country producing the same product with the same level of emissions. For simplicity, assume that, prior to the implementation of environmental controls, each industry produced just enough to meet its home demand, and the price was the same in both countries. As a result, trade did not occur. ${ }^{13}$ Suppose, because of different preferences, income levels or assimilative capacity, it is optimal to impose environmental controls in one country but not in the other. What happens to price, output and en. vironmental quality in the two countries? ${ }^{39}$

The answer depends in part on whether the two countries can trade. If trade does not occur, the effect is the same as in the previous example. As figure 1 shows, in the country where pollution controls were imposed, the price will rise to $P_{2}$ and the quantity of output will fall to $\mathrm{Q}_{2}$, while in the other country noth. ing changes. Figure 2 shows the effect of an emissions tax on price and output in the two countries when trade occurs. ${ }^{20}$ The reduction in supply of the chemical in the taxed country (Tax) will reduce the world supply of that product, causing the world supply curve to shift upward to the left. At the new world equilibrium $D$, the price, $P_{3}$, is lower than the autarkic (no trade) equilibrium price in $\operatorname{Tax}\left(\mathrm{P}_{2}\right)$, but higher than the autarkic equilibrium price in the other country, Notax $\left(P_{1}\right)$. At $P_{3}$, consumers in Notax demand $\mathrm{Q}_{4}$, but firms are willing to supply $Q_{5}$. The distance $X_{2}$ is exactly equal to the distance $X_{1}$, which measures the difference between what firms in Tax are willing to supply at $\mathrm{P}_{3}\left(\mathrm{Q}_{4}\right)$ and what consumers demand at that
17See, for example, Grossman and Krueger (f991).

${ }_{18}$ This example generalizes to the case where trade occurs before the implementation of environmental controls.

19 This section assumes that each country is large enough to affect the world price. If the country with the emissions tax was a small country, it could not affect the world price. As a result, the effect on output in that country would be greater than in the example above.

20This assumes prices are in the same currency, so all exchange rate effects are ignored. 
price $\left(\mathrm{O}_{5}\right)$. As a result, Notax exports the quantity $\mathrm{X}_{2}$ of the chemical to Tax.

What is the effect on other economic variables? Consumption of the chemical falls in Notax, even though output rises. In general, because of the increased production in Notax, there will be an increase in pollution emissions in that country. How much the pollution level actually increases in Notax (if at all) depends on the assimilative capacity and the method of production used in that country. Whether the people in Notax are better off at the potentially higher level of pollution that resulted from increased production depends on that country's willingness to accept higher pollution for higher income.

Pollution declines in Tax. If the assimilative capacity is higher in Notax, world pollution will likely be lower after environmental controls are implemented. The effect on world employment is ambiguous and depends on certain countryspecific variables. The terms of trade will deteriorate for the country with the emissions tax.

If the new level of emissions in each country is optimal given preferences and income, both countries are better off by trade. The taxed country is able to consume more at a lower price than in the autarkic case, while the value of total output rises in Notax. If measures of national income or wealth accurately reflected environmental damage, they would increase in both countries.

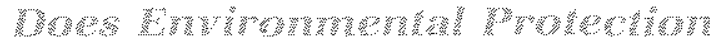

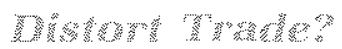

One concern is that environmental regulation unfairly discriminates against domestic firms when they compete with firms in a country that has lower environmental standards. In the example discussed above, an externality existed in Tax but, by assumption, not in Notax. As a result, introducing environmental controls eliminated a distortion that previously existed. This changed the flow of trade, but caused all the costs of using the environment, both as inputs in production and as consumption items, to be reflected in market prices. Thus, assuming that environmental quality was not socially optimal before protections were enacted, pollution-intensive sectors in Tax were actually receiving an implicit subsidy from those who had been incurring the external costs of pollution.

The difficulties in trying to determine the optimal amount of environmental quality within a country, as discussed above, are substantial. The optimal level of environmental quality in one country is unlikely to be optimal in another, particularly if the two countries have significantly different income levels. Attempting to impose one country's environmental standards on another by using import restrictions does not allow countries to capitalize fully on their comparative advantage. ${ }^{21}$ As discussed later, it is also illegal under current international trading rules.

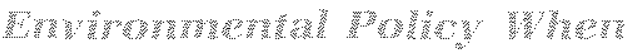

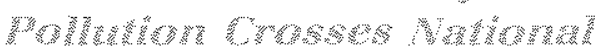

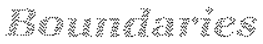

The previous section discussed the interna tional effects of environmental policy when environmental damage is contained within national borders. Many other uses of the environment cause environmental damage across borders, such as acid rain, which results from sulphur dioxide emissions, or worldwide, such as ozone depletion, which results primarily from chlorofluorocarbons (CFCs). Transfrontier pollution may occur in essentially four ways: ${ }^{22}$

1. A firm's production takes place in one country, but pollutes only in another.

2. Both countries have firms whose production processes pollute, but each country's pollution is experienced only in the other country.

3. Pollution occurs as a result of production in one country but the effects are felt in both countries.

4. Both countries pollute, and the pollution generated by each is felt in both countries.
21If Tax puts trade restrictions on imports of chemicals from Notax because of the lack of emission restrictions in Notax, both countries would be worse off. lit, for example, a tariff was levied against imports from Notax, the earnings in Notax from exporting the chemicals would be lower. Consumers in Tax would pay a higher price and import a lower quantity as a result of the tariff. For a detailed discussion of the effects of tariffs on trade, see Coughlin,
Chrystal and Wood (1988). For a discussion of the possible application of trade and policy measures in relation to environmental problems, see Subramanian (1992).

22See Lloyd (1992). 
If pollution is of form 1 or 2 , in the absence of an international agreement, the polluting country has no incentive to curtail its polluting activities by implementing an environmental policy. If, instead, pollution is of the form 3 or 4, pollution may be regulated domestically. Without taking into account the pollution in the other country, however, these controls will not likely be optimal internationally. In the absence of a globally optimal intemational agreement, domestic policymakers have less incentive to take into account the costs imposed on a foreign country than if the costs were borne domestically. Thus, from a global perspective there will be excessive use of the environment.

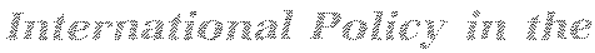

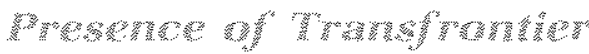

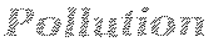

Suppose, as in case 1 , the river being polluted by the chemical firm runs directly into another country and all the towns affected are in the foreign country. How is an appropriate policy determined? Previously, we assumed that a country weighed the costs and benefits of pollution, given its preferences for environmental quality, its income level and its assimilative capacity. Unfortunately, in the case of transfrontier pollution, this is no longer sufficient. In this case, domestic policymakers will be less concerned with the costs imposed on a foreign country than those borne domestically. In addition, the desired level of pollution could differ significantly between the two countries because of their preferences and income levels. Other issues contribute to the difficulties in negotiating an international agreement on pollution control. For example, should the polluter pay to reduce emissions or should the residents of the country affected by the pollution pay to induce the firm to reduce emissions?

In the early 1970 s, countries belonging to the Organization of Economic Co-Operation and Development (OECD), the multilateral organiza* tion of the industrialized countries, adopted the Polluter Pays Principle (PPP) to deal with purely domestic pollution. ${ }^{23}$ This principle requires that the polluter bear the cost of pollution-reducing measures. This approach, however, provides no guidance about how to determine environmen* tal damage or what to make the polluter responsible to pay for. For example, should a polluter be responsible for damage that has already occurred, or should it be required only to pay to reduce current emission levels? In addition, PPP offers no instruction regarding transfers between governments to resolve problems of transfrontier pollution.

As a result of an OECD conference on transfrontier pollution, it was suggested that the OECD adopt the so-called "mutual compensation principle." This proposal requires the polluting country to provide an estimate of the costs of pollution abatement for various levels of pollu. tion, while the polluted country similarly provides an estimate of the costs of treating the damages. An independent agency determines the optimal level of pollution with these two cost functions. Given the level of pollution set by the agency and the cost functions provided by the two countries, the polluting (polluted) country pays a pollution (treatment) tax based on the cost of clean-up (control) estimated by the other country and is also required to pay for the cost of pollution abatement (clean-up) in their own country. The advantage of this approach is that it induces countries to reveal their "true" value of the environment." Unfortunately, because of the problems inherent in determining the optimal level of pollution as well as negotiating and implementing such a proposal, the mutual compensation principle has never been used.

There are other impediments to reaching international agreements on environmental use. For certain types of environmental degradation, there is debate about how much damage is actually being done to the environment. An obvious example of this is global warming. ${ }^{25}$ Many environmentalists and governments are concerned that excessive emissions of carbon dioxide, nitrogen oxide and methane gas from energy use are irreversibly warming the planet. Many others, including the U.S. govermment, however, feel that the evidence is insufficient at this point and are unwilling to significantly alter their environmental policy. Scientific evidence on global warming is inconclusive. An August
23These countries are the 24 main industrialized countries.

24 See OECD (1976) for an analytic discussion of why this is true. For more information on the mutual compensation principle, see the discussion therein.
${ }^{25}$ For a discussion of the effects of global warming see, for example, Winters (1992) and Schelling (1992). 
31, 1991, survey on energy and the environment in The Economist pointed out one of the difficulties with transfrontier environmental damage such as global warming: the appropriate policy may need to be implemented before conclusive proof that the damage appears, because of the cumulative effects of some types of environmental damage over time.

Nevertheless, some international agreements have been reached (see table 1) and, if the significant increase in articles, studies and conferences on transfrontier pollution are any indication, there will be additional pressures to find new ways to deal with the increasing problem of transfrontier pollution.

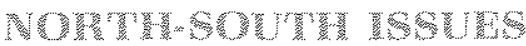

One of the main reasons environmental policy affects trade is because countries are at different levels of industrialization and thus have different income levels, which can cause their optimal levels of pollution to differ. Because the interests between high-and low-income countries may differ, it is important to look more closely at these so-called North-South issues, ${ }^{26}$

Currently the industrialized countries, in general, are greater polluters than less industrialized countries and thus tend to put a relatively greater demand on worldwide assimilative capacity. One concern heard in developing countries is that industrial economies, rather than reducing their own demand for assimilative services, could impose their environmental standards on developing countries without any assistance in paying for them, thereby reducing the opportunity for less-industrialized countries to grow. As one news commentator suggests:

Developing nations are suspicious that bornagain environmentalists in the North will saddle them with commitments to regulate pollution, slow down deforestation, and control population growth, all in the name of sustainable development, yet won't follow through with economic aid to improve their own productivity and employment. Meanwhile, developed nations are reluctant to undertake radical domestic [environmentall policy changes that threaten their own economic growth. ${ }^{27}$

Other types of environmental issues have a particular North-South nature. For example, many of the world's nature preserves are in developing countries in Africa. Currently, trade in elephant hides and ivory, along with other endangered species, are prohibited under the Convention on International Trade in Endangered Species (CITES). At a recent conference on CITES in Kyoto, Japan, several African countries argued that their elephant herds are large enough to be culled without endangering the species. In addition, they argued, revenue generated by the sale of ivory and other elephant products is needed to fund future preservation.

Here, the interest of the industrialized countries, who do not have a native elephant population, is to protect an endangered species. The African countries, however, face a tradeoff between the benefits of protecting the species and the loss of revenue associated with the prohibition of trade in elephant products. ${ }^{28}$ As a result, less-industrialized countries are putting increased pressure on industrialized countries to help pay for the services they are providing (such as species diversity).

In March 1992, the General Agreement on Tariffs and Trade (GATT), the main body regulating international trade, released a report entitled "Trade and the Environment" that takes a non-traditional approach to North-South problems. One hotly debated issue concerns the protection of the rainforests, most of which are located in Latin America. ${ }^{29}$ Industrialized countries have moved to bar wood imports from Brazil and Thailand, for example, as a way to reduce deforestation in those countries. GATT argues that, rather than barring imports of wood products (much of which is GAT'T-illegal), the industrialized countries should compensate rainforest countries for providing "carbon absorption services."

Although this approach is novel, its advantage is that poorer countries are assisted with financ.

${ }^{26}$ For a more complete discussion of North-South issues in envitonmental economics, see Walter (1975).

27Walter Truett Anderson, in Walljasper (1992), p. 159.

29Ranforests are valued for, among other things, theil ability to reduce carbon dioxide in the air and for the biological diversify they contain.

2eAt the close of the Kyoto conference, the calls for partially opening trade in elephants and minoceroses were ignored. 


\section{Table 1}

\section{Examples of Multilateral Environmental Agreements with Trade Provisions}

Convention Relative to the Preservation of Fauna and Flora in their Natural State, 1933

Objective, to preserve the natural tauna and flora of the world particularly of Africa, by means of hational parks and reserves, and by regulation of hunting and collection of spectes.

Trade Proviston prohibits the import and export of trophies unless the exporter is given a centificate permiting export Paties shall take neasures to control and regulate in each of ts teritories the internal import and export of trophies acquited in a nanner not n accord with national law (Art X).

Convention on Nature Protection and Wildife Preservation in the Western Hemisphere, 1940 ?

Objective, lo preserve all species and genera of native American fauna and lora from extinction, and to preserve areas of extraordinary beauty, strikng geologleal formation or aesthetic historic or seientilo value

Trade Provision provides for the regulation of trade in protecled specles by the issuance of export permits (Ar. $X)$

\section{African Convention on the Conservation of Nature and Natural Resources, $1968^{\circ}$}

Objective: 0 conserve, utlize and develop the soil wate, floral and faunal resources of the Alrican continent.

Trade Provision for all species, a Party shall regulate trade in and the transport of spect mens or trophies, and shall 00 so in such a mamer as to prevent the llegal capture or kiling of these. Trade in trophies and tronsport of spectmens of protected specles shall be subject to a standard authorization 0 additional to that lequired for the huning, kiling, capture or collection. (1) which ndicates the desthation, (ii) which shall hot be given unless they have been legally obtained, (y) which shall be examined prior to exportation. Parties wil nake the import and transit of such specintens or trophies subject to the presentation of the authoriza.

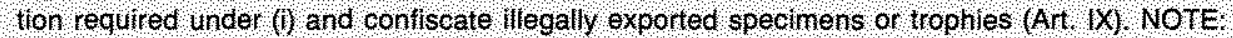
Parties are all members of the Organization of Atrican Unity

ing environmental protection, so that it does not come at the expense of economic development. This approach also reduces the free-rider problem that enables much of the world to benefit from the carbon absorption services provided by rainforests and the diversity of species provided by countries that are not the primary users of the environment. In addition, the approach directly protects the rainforests, rather than barring certain types of wood products in the hopes that doing so will cause the exporting countries to protect them.

Other approaches taken to improve environmental standards in lower-income, less-industrialized countries include debt-for-nature swaps. Here, foreign debt is purchased by environmental groups and sold back to the issuing governments in exchange for investment in local envirommental projects, including the purchase of land that is then turned into environmental preserves. ${ }^{30}$

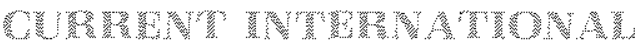

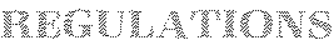

At present, international agreements do not allow a country to discriminate against products based on their production techniques. Under GATT, barring imports because the production methods used do not meet the standards of the importing country is illegal. This rule has come under fire recently, particularly in light of the 
Table 1 (continued)

\section{Examples of Multilateral Environmental Agreements} with Trade Provisions

Convention on nternational Trade in Endangered Species of Wild Fauna and Flora, $1973^{4}$

Objective, to protect endangered specles aganst overexploitation through international trade.

Trade Provisions, trade of species threatened with extinction (isted in Appendix I) and trade in species that may become endangered unless rade is stictly regulated flisted in Appendix 11., is authorized by export and import permits approved by the Sclentific Authorties of the Parties concerned (Articles III and M, Species that a Party dentfles as being subject to regulation within is own urisdiction and as requiring international cooperation to control trade (isted in Appendix ily is subjed to an export permit authorized by the Sclentitic Authority of the Paty (Article V, Article XXII permits a party to exempl iself from the requirements of the convention with regard to a specific species Isted in Appendices I, 11 or 11. NOTE CITES buids on a long history of controlling trade in endangered species through the issue of export pernits. It adds the wist of requiting an import permit for an export per mil to be issued, in order lo prevent circumvention to non Parties.

Montreal Protocol on Substances That Deplete the 0zone Layer, 19875

Objective to reduce and eliminate nan-made emissions of ozore-depleting substances.

Trade Provisions trade provisions affect non Parties only, Parties are to ban the importation of controlled substences as of January 1, 1991 and ban the export of controlled substances as of January 1, 1993 Parles are also to ban the export of the relevant technology to non Partes, The 1950 amenoments, which are not in force, requite Parties to ban the importation of CFC containing products as of January $1,1993$.

SOURCES, GAT T (1992) and U/S, Department of State (1991)

The signatory countles are, Belgum, Italy Portugal, Spain, Sweden, United Kingdor, Egypt: South Aftica, United Republic of Tanzania and India. For notes regarding certain colntries, please consult or ginal source.

2The signaton countiles are. United States, Argentina, Brazit Chile, Costa Rica, Doninicen Pepubilc, Ecuador, El Salvador, Guatemala, Hait, Nexico, Noaragua, Panama, Paraguay, Peru, Suriname, Trinidad and Tobago, Uruguay and Venezuela, for notes regarding certain countries, please consult orighal source.

The signatory countries are, Algeria, Burkina Faso, Cameroon, Central Alrican Republi, Con go, Dj bouti, Egypt, Ghana, Ivon Coast, Kenya, Liberia, Madagasoan, Malaw, Mall, Morocco, Mozambique, Nger, Nigeria, Rwanda, Senegal, Seychelles, Sudan, Swaziland, Togo, Tunisia, Uganda, United Republic of Tanzania, Zaire and Zambla for notes regarding certan coun tries, please consult original source.

The signatory countries are all OECD countries except Greece, lceland, lreland and Turkey: Argentina, Brazil, Costa Rica, Venezuela, Congo Egypt, United Republic of Tanzania, Zaire Zimbabwe, India, Indonesia, Malaysia, Union of Soviet Soctalist Republics and Istael, plus 73 other developing countries for notes regarding cettain countries and for Appendices III and 11, please consult original source

5 The signatory countries are. All OECD countries except Turkey, Argentina, Brazil, Mexico, Egypt, Kenya, South Atrica, Zambia, Malaysia, Thaifand, Union of Soviet Socialist Repubtics Bulgaria, Czechoslovakia and Hungary, plus 25 other developing countries. For notes regardIng certain countries please consult original source

controversial tuna-dolphin dispute between the United States and Mexico. ${ }^{31}$

The justification for prohibiting trade restrictions based on the production method is to prevent countries from using such restrictions to protect domestic industries. Unfortunately GATT was not designed to address some of the more complicated issues of environmental protection, particularly regarding production methods that could have transborder or global 31n this case, the United States barred Mexican luna because the process by which is caught tuna killed more dolphins than is permitted by the United States. According to GATT, however, the ban was illegal because the fishing waters in question were not under U.S. jurisdiction. Fo: a discussion of the tuna-dolphin case, see GATT (1992) or the original panel report 


\section{GATT and the Environment}

GATT is a multilateral trade agreement that sets the rules for international trade, provides a mechanism by which to settle trade disputes among countries, and conducts multilateral trade negotiations (called Rounds) to reduce trade barriers. The agreement. however is silent concerning the complica: tions stemming from environmental polieies that have trade effects. The only article that remotely deals with the environment is Article XX, which lists general exceptions to GATT rules. Under Article XX:

Subject to he requirement hat such neasures are not applied in a manner which would constitute a means of ar bitrary or unjustiflable diserimination be Ween countries where the same conditions prevall, or a disguised restriction on inter national trade, nothing in this agreement shall be construed to prevent the adop tion or enforcement by any contr acting parlies of measures, necessary to ploted human, animal or plant lfe or health:

Under GATT, countries can regulate polluting firms in their own country as long as no distinetion is made between domestic and foreign-owned firms. In fact, nothing in GATT restriets a government's autonomy in such things as taxation, regulation and subsidies as long as foreign and domestic firms are treated equally.

In regard to polluting consumption goods (e,g, cars that produce air pollution), it is also GATT legal to place controls on these products, or require pollution control devices (such as catalytic converters), as long as these regulations are applied equally to domestically produced and imported. products. These regulations tend to be applied equally, eausing fewer trade-related problems with consumption pollution.

According to the recent GATT report on the environment, In principle, it is not possi- ble under GATT's rules to make access to one's own market dependent on the domestic environmental policies or practices of the exporting country"'? As a result, two primary sources of conflict have arisen between environmental policy and GATT. The first is the violation of the national treatment provision, which states that foreign firns producing or seling a product in a country must be treated the same as a domestic firm lie, a foreign firm located in another country cannot be subject to more stringent environmental standards than a domestic firm), The second is violations of the non-discriminatory status which states that any trade concession made to one GATT member nust be made to all. ${ }^{3}$. For example, the trade provisions of the Mon treal Protocol stipulate different trade meas. ures for signatories and non signatories lotherwise known as most favored nation (MFN) status], which is a violation of non. discrimination.

There are several ways that environmental issues could be explicitly addressed in GATT: The rules could be amended for example, to set up a penalty system for countries that are below some agreed-upon level of environmen tal standards. This requires acceptance by twothirds of the contracting parties (in which countries it thereby becomes effectivel and is effective in the other countries as they accept the amendment. The difficulty with this ap proach is that a sufficient number of nember countries must agree to the "acceptable" standards. Even if there are different provisions for developing and industrialized countries, agreement is still likely to be difficult.

Another possibility is that specific waivers may be granted to all or some of the signatery countries. This waiver requires a twothirds majority of those voting, as long as the

$1 \mathrm{GATT}(1986)$, p 37

rGAT (1992), p 10

There are, however, GATT sanctioned exceptions to: nondiscrimination, such as the Generafized System of Preferences for developing countries. 
majorty comprises at least half of the cont tracting parties. Waivers, howevel, are not assumed to be long tern solutions, but exceptions for a Imited time.

CATT could also darify whether WEN and national ueatment, which requires equal heat ment for $1 \mathrm{ike}$ products consider products that are produced with significantly diflerent envronmental standards as $91 \mathrm{ke}$ prodacts $1 \mathrm{f}$ not, they can be subject to different regula tions. The advantage of at of these ap proaches is that hey address enviromental
Issues In a Iransparent, multhateral way and are not used to mask protedtionist policies.

The concem that notivated the recent GATT study is that lrade policies justified by a trading partner's environmental pollcies are aften simply another way to protect a domes 1e thdustry at the expense of $1 \mathrm{~s}$ foreign competitors, The next set of GAT I talks will likely attempt to make explict rules about environmental policy 10 prevent differences in these policies from being used as a new ype of non tariff barties. effects. ${ }^{32}$ For a discussion of GA'T regulations and environmental protection, see the shaded insert at left.

GAT'T's recently released report on the environment attempts to address some of these issues. Some have suggested, in addition, that GAT'T focus the next round of talks on environmental issues (assuming the current "Uruguay Round" of talks is successfully completed. ${ }^{33}$ "The United Nations-sponsored "Earth Summit" in Rio De Janeiro scheduled for this spring is also an attempt to increase international cooperation on protecting the environment, particularly in regard to North-South issues.

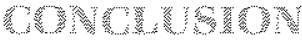

This article examines the role of environmental policy on international trade. Environmental policy is justified because of the nature of externalities associated with using the environment. When the divergence between the social and private costs of using the environment is ignored, polluting activities receive an implicit subsidy. Environmental regulations may change international trade, but enhance social welfare by removing this subsidy. The optimal amount of environmental protection, however, can differ significantly across countries because of differences in preferences, income and assimilative capacities.

One important concern is that countries will use environmental policies as an excuse to establish protectionist policies. As environmental protection and environmental use take on a more transnational nature and the assimilative capacity is reduced worldwide, new agreements will have to be designed to both protect scarce resources and protect countries from being discriminated against because of how they choose to use their environmental endowments domestically. As the recent GATT report suggested, however, it is possible to protect the environment without distorting trade flows. Thus, free trade and environmental policy are not mutualy exclusive but can work together to encourage both economic growth and environmental quality worldwide.

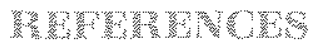

Anderson, Kym, and Fichard Blackhurst, eds., The Greening of World Jrade issues (University of Michigan Press, 1992).

Baumol, William J., and Wallace E. Oates. The Theory of Environmental Policy, 2nd ed. (Cambridge University Press, 1988).

Blackhurst, Richard. "International Trade and Domestic Environmental Policies in a Growing World Economy," in Richard Blackhurst et al, eds., International Relations in a Changing World (Sijthoff-Leiden, 1977), pp. 34i-64.

Browning, Edgar K., and Jacqueline M. Browning. Public Finance and the Price System, 2nd ed. (MacMillan Publishing Co., Inc, 1983).

Charnovitz, Steve. "Exploring the Environmental Exceptions in GATT Article XX," Journal of World Trade (September 1991), pp. 37-55.

Coase, R. H. "The Problem of Social Cost," The vournal of Law and Economics (October 1960), pp. 1-44.

Coughlin, Cletus C., K. Alec Chrystal, and Geoffrey E. Wood. "Protectionist Trade Policies: A Survey of Theory, Evidence and Rationale." this Review (JanuaryfFebruary 1988), pp. $12-26$.

${ }^{33}$ For an additional discussion of why GATT should look more closely at environmental regulation, see Petersmann (1991).
32For a comprehensive discussion of the application of environmental exceptions under GAT, see Charnovitz (1991), and Sorsa (1992). 
Devlin, Robert. "Debt-tor-Nature Swaps: A New Agenda," international Economic insights (September/October 1991), pp. 33-37.

GATT. The Text of the General Agreement on Tariffs and Trade (Geneva, July 1986).

. Press Release \#1529, February 3, 1992.

Grossman, Gene M., and Alan B. Krueger. "Environmental Impacts of a North American Free Trade Agreement," prepared for the Conference on the U.S.Mexico Free Trade Agreement, October 3, 1991

Lloyd, Peter J. "The Problem of Optionat Environmental Policy Choice," in Kym Anderson and Richard Blackhurst, eds., The Greening of World Trade Issues (University of Michigan Press, 1992), pp. 49-72.

Mishan, E. J. Cost-Benefit Analysis: An Introduction (Praeger Publishers, 1971).

Nicholson, Walter, Microeconomic Theory: Basic Principles and Extensions, 3rd ed. (Dryden Press, 1985).

Nicolaisen, Jon, Andrew Dean, and Peter Hoeler. "Economics and the Environment: A Survey of issues and Policy Options," OECD Economic Studies (Spring 1991). pp. $8-38$.

OECD. Economics of Transtrontier Pollution (1976).

Economic Surveys: United States. Protecting the Environment (November 1991).

Petersmann, Ernst-Uirich. "Trade Policy, Environmental Policy and the GATT: Why Trade Rules and Environmental Rutes Should be Mutualy Consistent," Aussenwirtschaft, 46, Jahrgang (1991), pp. 197-221.

Pigou, Arthur C. Economics of Welfare, 4 th ed. (MacMillan and Co., 1952).
Schelling, Thomas C. "Some Economics of Global Warming," American Economic Review (March 1992), pp. 114.

Siebert, Horst. Economics of the Environment: Theory and Policy, 2nd ed. (Springer-Verlag, 1987).

Sorsa, Piritta. "GATT and Environment," in David Greenaway and John Whalley, eds., The World Econorny (January 1992), pp. 115-31.

Subramanian, Arvind. "Trade Measures for Environment: A Nearly Empty Box?" in David Greenaway and John Whalley, eds., The World Economy (January 1992), pp. $135 \div 52$.

Tietenberg, T. H. "'Economic Instruments for Environmental Regulation:" Oxford Review of Economic Policy (Spring 1990), pp. 17-33

U.S. Deparment of State. Treaties in Force: A List of Treaties and other International Agreements of the United States in Force on January 1, 1997 (September 1991).

Wallasper, Jay. 'The AntinGreen Backlash,"' Uthe Reader (March/April 1992), pp. 158-59.

Walter, Ingo. International Economics of Pollution (Halsted Press, 1975)

"Weatth of Nature," The Economist (January 18,1992 ), p. 67.

Winters, Alan L. "The Trade and Welfare Effects of Greenhouse Gas Abatement: A Survey of Empirical Estimates," in Kym Anderson and Richard Blackhurst, eds., The Greening of World Trade Issues (University of Michigan Press, 1992), pp. 95-114 